\title{
The Role of Entrepreneurship Education on Internationalization Intention. A Case Study from Izmir-TURKEY
}

\author{
Dinçer YARKIN \\ Department of Logistics Management \\ Gediz University, Turkey \\ dincer.yarkin@gediz.edu.tr
}

Yeliz YEŞiL

Söğüt Vocational School Bilecik Şeyh Edebali University, Turkey

yeliz.yesil@bilecik.edu.tr

\begin{abstract}
Acting in a domestic market can be risky for new ventures in developing countries because of vulnerable economic and politic conditions. From the beginning of establishment, focusing on international markets can prevent local market risks which new entrepreneurs will probably encounter. Internationalization, entrepreneurship and international entrepreneurship are the main topics which scholars given more attention in the world. In this study, entrepreneurship education and it's effects on generating internationalization intention were evaluated by in depth interviews. Findings has shown that type of the institute, course content, classmates, qualification and background of the lecturer, plays important role on initiation of starting international business.
\end{abstract}

Keywords: Entrepreneurship, Entrepreneurial Intention, Entrepreneurship Education, Internationalization.

\section{Introduction}

There are strong links between Entrepreneurial activity and economic outcomes such as economic growth and innovation, and creating economic efficiency, creating new jobs, (Shane and Venkataraman, 2000; Oosterberbeek, Praag \& ljsseltein, 2010). Thus, there has been seen growing attention on entrepreneurship education organized by governmental institutes and universities.

In USA, Office of Entrepreneurship Education (OEE) develops and promotes innovative resources for small business owners and prospective entrepreneurs for 40 years . (https://www.sba.gov/offices/headquarters/oee/about-us) In Europe, According to EC (European Commission) Entrepreneurship is a key competence for lifelong learning, as defined in the 2006 European Framework for Key Competences. The commission states that, they are committed to promoting education for entrepreneurship at all levels, from primary school to university and beyond.( http://ec.europa.eu/enterprise/policies/sme/promoting-entrepreneurship/education-training-

entrepreneurship/index_en.htm). The dominant entrepreneurship education program in secondary school and colleges in the US and Europe is the Junior Achievement Young Enterprises student mini company (SMC) program. In Europe, it is effective in 40 countries and more than 2 million students have participated in the year 2005/2006 (Junior Achievement Young Enterprise Europe Annual Report, 2006; Oosterbeek, et.al., 2010:443).

In Asia, especially ASEAN member countries focused on entrepreneurship education. The ASEAN secretariat and Japan Overseas Development Centre (JODC) has implemented entrepreneurship education for in Thailand, Cambodia, Malaysia and Indonesia since 2003. Asia SEED as the executing organization that implements the seminars for entrepreneurship education for Vietnam, Myanmar and Philippines (http://www.asiaseed.org. Retrieved on 10 ${ }^{\text {th }}$.Nov.2015). 
Kaijage and Wheeler (2013), made highly appreciated study on East Africa and shared suggestions about entrepreneurship education according to their research implications. Jesselyn Co and Mitchel (2006) has conducted a survey among academic staff and tried to find out, status of entrepreneurship education in South Africa. In 2007, Isaacs and friends also focused on level of South African Entrepreneurship Education. Even these kind of studies, there has not seen concrete effort on entrepreneurship education yet. According to stated authors these educations are still in developing phase.

Entrepreneurship education effects people positively in the journey of entrepreneurship (Kigechi, et.al., 2013). Qualification of educators, their experiences, leadership and vision plays great role for the future of entrepreneurship (Vesper,1999; Stevenson,2000; Solomon, 2002) According to Kuratko (2005), educators should use their ability for leading , pioneering their universities into a new horizon. McMullan (et al., 2002) provide some evidence that these programs are successful in encouraging entrepreneurs to start businesses, or improve the performance of businesses. (Peterman and Kennedy,2003:131).

\section{Entrepreneurial Intention}

Research on entrepreneurial intentions mainly depends on Ajzen's (1991)theory of planned behaviour(TPB), and Intentions-based models provide practical insight to any planned behaviour (Krueger and Carsrud 1993; Krueger,et.,al.,2000; Gelderen, et.,al., 2008; Wu and Li 2011), Entrepreneurial intentions, entrepreneurs' states of mind that direct attention, experience, and action toward a business concept, set the form and direction of organizations at their inception (Bird,1988:442). Applied to the entrepreneurial context having stronger feeling, and intention on entrepreneurial activity, supports entrepreneurial activity (Kautonen et.al.2013) and entrepreneurial intention means someone who is willing to start a new business (Krueger,1998). Entrepreneurial behaviour has become more and more common, calling for better entrepreneurial skills and abilities for dealing with current challenges and uncertain future (Heionen and Poikkijoki, 2006:81).

\section{Entrepreneurship Education in Turkey}

In Turkey entrepreneurship courses are given by Universities and in the coordination of KOSGEB (Republic of Turkey, Small and Medium Enterprises Development Organization) and Turkish Labour Agency. For technology oriented entrepreneurship TUBITAK (The Scientific and Technological Research Council of Turkey) has the authorization of organizing entrepreneurship courses.

In universities this courses are especially designed for last year students of Business Administration as compulsory, for engineering students as elective and takes approximately 40 hours per one semester.

KOSGEB Entrepreneurship, includes training and workshop studies of minimum 70 hours (testing of entrepreneurship abilities, business idea exercises and business plan preparation) Applied Entrepreneurship Trainings can be organized by KOSGEB (or other foundations or institutes (universities, ISKUR, Turkish Labour Agency), professional organizations, municipalities etc.) Trainings are arranged for general and specific (young, women, and disadvantageous groups) target groups. TUBITAK mainly focuses on technology oriented start-ups and provides funds from the beginning of establishment till getting patents for developed new products.

\section{Research Method}

In this is study interpretive and exploratory approach is used for understanding, the role of entrepreneurship education not only by course content, but also other environmental and lecturer based issues-on internationalization intention of entrepreneur candidates. Research Sample was chosen by the population who have right to got certificate after 70 hours of course between May 2014-November 2014 in Izmir-Turkey, given by Universities, ISKUR (Turkish Labor Agency), Municipalities, Governor and Chambers Of Commerce (Organized by KOSGEB). There are 5 people from different institutes from different locations; totally 15 people was chosen for research. Totally 15 series of interviews made in 10 hours between 1th Dec.2014-30thDec.2014.Compherensive framework is developed for better understanding of internationalization intention after entrepreneurship education. 


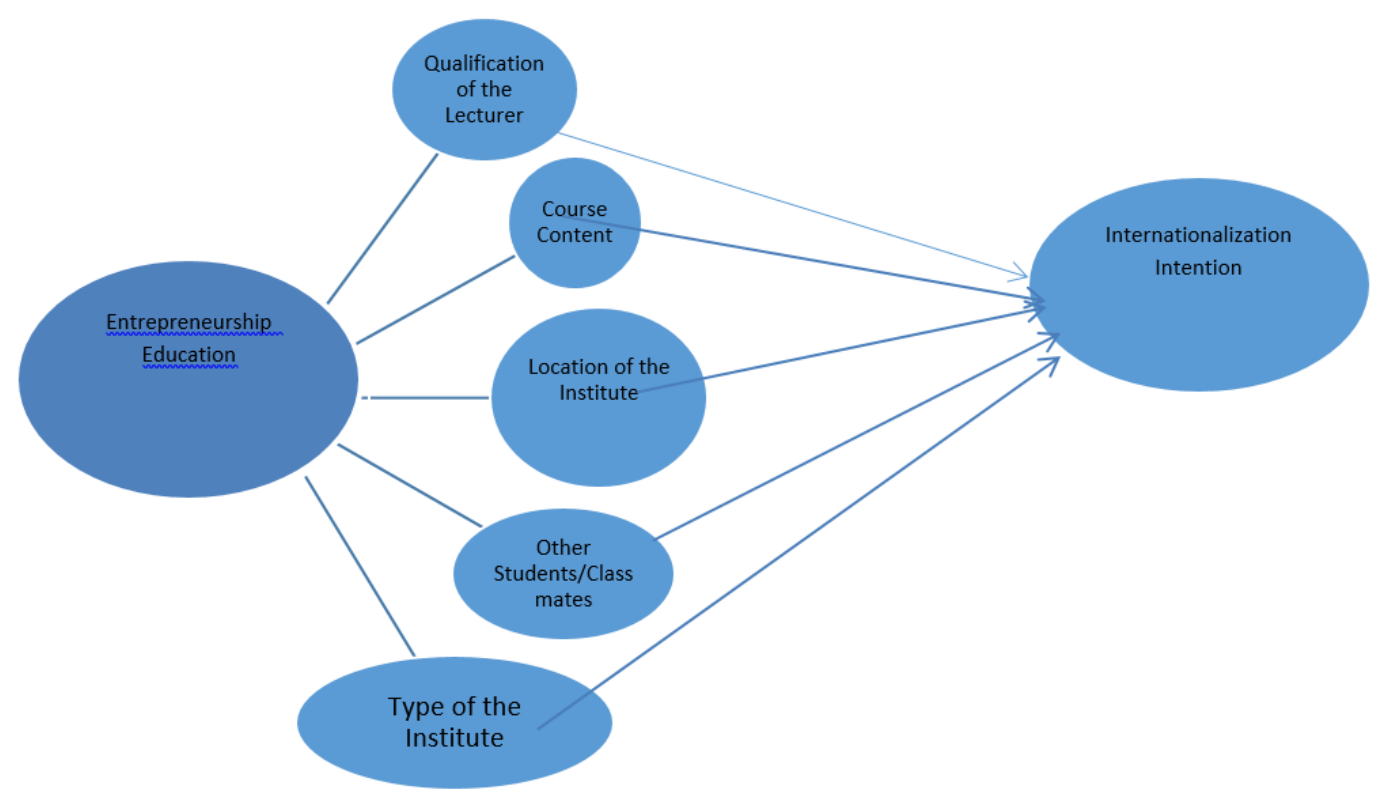

Figure 1: Conceptual Framework

\subsection{Findings}

In this study, qualification of the lecturer, course content, location of the institute, classmates, type of the institute were found as basic determinants of entrepreneurship education, which were also effects internationalization intention of new candidates.

\subsubsection{Location}

"Our course centre was one of the small campuses of a university in the centre of Izmir. We were having lunch in restaurants where white collar staffs, businessmen and businesswomen went usually. This was really important for me, because observing them was motivating me" (Age 23, University Student, Woman, S.K.).

"We took this course in Chamber of Commerce in City Centre of Izmir, where high businessmen from different sectors is seen inside and outside. And after course times we are hanging out with classmates, during this period, we had chance to know each other, and share future plans, It was a great experience for me" (Age 27, Man, Bachelor Degree, GB).

"Our course centre was $80 \mathrm{~km}$ far from city centre, in a small town. I did not have chance hang out with my friends because there is no proper cafes, something like that around us. After course time we were leaving to go home. I wish I listened to my classmate's projects after course times"(Woman, 34, Primary School Graduate F.E).

According above data, it is not easy to find out the role of location on internationalization intention of entrepreneurship students. But it is clearly seen that, location affects, entrepreneurial motivation of entrepreneur candidates. Spending time together after course period, helps students to discuss entrepreneurial issues and providing network potential to them. 


\subsubsection{Type of the Institute}

"In university during the break times, I saw students from different countries who are in the same age with my daughter. It was really exciting experience for me. I came this course for get incentive from KOSGEB for running coiffeur business. I have no chance, or qualification for doing business abroad. But I will motivate my daughter about focusing on international entrepreneurship for her future career, who is now university student" (Age 46, Woman, Secondary School Graduate, F.E.).

"We took this course in Chamber of Commerce in City Centre of Izmir, where high businessmen traffic is seen inside and outside. After I start my own business I will be there as businessman like others. Experiencing this atmosphere during the course is valuable"(Age,29, Woman, Bachelor Degree, I.C.).

"Our entrepreneurship courses organized by local businessmen association, which held in small conference room of primary school, but our lecturer was from an university. I preferred to be different place which will more suit us as entrepreneur candidates, future's businessmen and businesswomen. There were no motivational instruments, surrounded us" (Age 30, K.E.Woman, High School Graduate).

Getting entrepreneurship education from universities has strong impact on becoming entrepreneurs (Peterman and Kennedy,2003;Saeed, et.al.,2013). According to Hamidi et.al., (2008) academic entrepreneurship programs provide higher intention to the audiences for starting their own business in the future. Our study also confirms that, universities which have international students has strong impact on entrepreneurial intention as well as internationalization. Chamber of Commerces because of providing experience of breathing same air with active businessmen or businesswomen, has significant impact on generating entrepreneurial intention.

\subsubsection{Classmates}

" $80 \%$ of my classmates are older than me and they are not well educated. They came course for getting fund from KOSGEB and open a small restaurant, Café something like that. I did not see any innovative business project ". (Age 24 , Man, Bachelor Degree M.T)

"One of my friend from the class was thinking about glass jar import. She told, she found contacts who were in need for glass jar. When I heard profit margin, I was shocked. After entrepreneurship course l've started foreign trade course. Now I am thinking about importing promotional staff from China to my friends"(Age 41, Man, High School Degree,0.D. ).

After these interpretations, we can refer to Brockhaus (2001), in entrepreneurship courses, student profiles are heterogeneous. Different education levels, different demographic structures can be seen in classes. Lans et al (2013), found that heterogeneity including disciplinary and cultural differences -contributed to learning within the groups but also caused confusion and misunderstandings. Segmentation among audiences is meaningful because of having different learning needs and own characteristics (Ghosh and Bloch, 1994). According to Rasmussen and Sorheim (2006), entrepreneurship programme may be generalising too much and contextualizing too little, and added an example "they are paying little attention to the selection and composition of the students".

\subsubsection{Course Content}

"I think 70 hours of course content was not enough. Especially for financial management part of that course is not satisfactory. As new entrepreneurs we should learn more details about financial statements, and we did not focused on preparing business plan so much" (Age 39, Woman , Bachelor Degree, N.A.).

"The course content is far from practical life. I have more than 10 years of business experience" I am not planning to establish holding company, those information given during classes are useless"(Age 33, Man, High School Degree, R.S).

"I attended to the entrepreneurship course, because $i$ want to establish a company for exporting hazelnut oil to the UK. We learned basic issues of how to run a business, but in the course content there is no any special topic related with international business or internationalization" (Age 47, Women, Vocational School Degree, F.C.Y.).

For effective learning, business plan plays crucial role. Focusing on business plan can provide experiential aspects to target audiences, which they will in need for their future's active business life (Timmons,et al.,1987; Hills,1988; Gibb, 1997; Henry et.al., 2005). 
Predictable and classical teaching methods can be boring for entrepreneurship students(Fiet,2000a), instead of that kind of methods learning by doing methods, providing set of circumstances which entrepreneurs will encounter in the future will avoid risks of demotivation (Fiet,2000b).

\subsubsection{Qualification Of The Lecturer}

"Our lecturer gave some examples from import-export business because of having experience in this area, multi-cultural nature of this business, attracting me" (Age 40, Woman,Bachelor Degree, B.C.).

Our Lecturer has 30 years of field experience, he is lecturing marketing and foreign trade courses in University as well. He lived in Australia, he has international view on entrepreneurship. He gave us practical and current examples, local and international basis (Age 28, Woman High School Degree, C.Y.).

"Our lecturer in Chamber of Commerce told us there is huge potential in the field of international business. \%90 of Chamber of Commerce Members do not know anything about import and export, and they're always seeking new markets" (Age 35, Man, Vocational School Degree, R.Y.).

"Our lecturer gave us an example about one his student from entrepreneurship course, 3 years ago she came to course for establishing a small production unit for baby textile. After the course, she went to the import-export course, and in the same year she exported organic fabric to the Germany. As English Literature graduate, it is hard for me to find a job as English Teacher in our country's condition. After I heard that example, I made a decision that, I should become intermediary , who finds customer abroad for local manufacturers, our finding suppliers for local buyer" (Age 25, Man, Bachelor Degree,T.D).

Vesper (1998) stated that, business general knowledge, venture general knowledge, opportunity specific knowledge and venture-specific knowledge are knowledge types which entrepreneurs need. for entrepreneurs there are mainly four kind of useful knowledge First two can be provided by academic educators but the sensitive last two, should be given by who has experience in the field and easily provide information about existing markets and production technologies.

Educators can invoke intention models to better understand our students' motivations and intentions, and thus provide better training (Krueger,et.al., 2000b). Entrepreneurial learning process to be enhanced through the provision of role models(Jack and Anderson,1999:117). Role models have influencing potential for choosing self-employment as a career (Sherer et al. 1989; Matthews and Moser 1995; Tkachev and Kolvereid,1999). From this point of view, even having not so much experience in the field, teachers should invite someone to the classes who locally or internationally doing business.

\section{Conclusion}

Getting more share from the world trade is always stated as main objective by developing countries . However in Turkey as developing country, $40 \%$ of the company owners have primary school graduation and only $\% 2$ of SME's are making Turkey's \%59,2 of export (http://www.tuik.gov.tr/PreHaberBultenleri.do?id=18521).

Current entrepreneurship educations should provide vision for internationalization. In Turkey, entrepreneurship educations has maximum ten years of past. And it is not easily said that standard methods using during the courses. Some courses are effective some are not.

Normally 70 hours of entrepreneurship educations are given by only one or two lecturers for KOSGEB Entrepreneurship Courses; in universities only one lecturer conducts entrepreneurship courses. But these courses have different modules; as entrepreneurial skills, marketing, production, finance, organization and management and business plan. Because of requiring more specialization, number and variation of lecturers (from academia and field) should be increased.

Interestingly during our interviews most of the people gave strong importance to the location of the institute and type of the institute. Most of the candidates even has primary school graduation has more motivation than the candidates even having undergraduate degree, who had the course far from the city centre. Courses given in Chamber of Commerce's provide strong contribution to the intention of entrepreneur candidates because of seeing active businessmen during break times.

Universities which have international students also provide quite contribution to the vision of entrepreneur candidates. Different languages, different races attract them and this tends to thinking about international businesses. 
Courses should be designed for the needs and qualification of entrepreneur candidates. In the first step of entrepreneurship education ,general aspects of entrepreneurship and main business functions should be given with the business plan and Course content should has some international business issues inside. According to motivation and interests of the entrepreneurship candidates, the second step should contain, details of international business .And this courses should be given by experienced lecturers, in main business areas of the cities.

\section{REFERENCES:}

[1] Ajzen, I, (1991), "The Theory of Planned Behaviour "Organizational behaviour and human decision process, 50, pp. 179-211.

[2] Brockhaus, R. (2001). Foreword. In Brockhaus, R., Hills, G., Klandt, H., and Welsch, H.(eds) "Entrepreneurship Education A Global View". Aldershot: Ashgate.

[3] Fiet, O., J., (2000), "The Theoretical Side of Teaching Entrepreneurship" Journal of Business Venturing 16, pp.1-24.

[4] Fiet, O., J. (2000), "The Pedagogical Side of Entrepreneurship Theory" "Journal of Business Venturing 16, pp. 101-117.

[5] Gelderen, M.Van, Brand, M., Praag Van, M., Bodewes, W., Poutsuma E., Gils, Van,A., (2008) "Explaining Entrepreneurial intentions by means of the theory of planned behaviour" Career Development International, 13(6), pp. 538-559.

[6] Ghosh, A. and Block, Z. (1994). Audiences for Entrepreneurship Education: Characteristics and Needs, In Hoy, F., Monroy, T. G., Reichert, J. (eds.), The Art and Science of Entrepreneurship Education. The Project for Excellence in Entrepreneurship Education.

[7] Gibb, A.A. (1987) "Enterprise culture-its meaning and implications for education and training”, Journal of European Industrial Training, 11(2), pp.1-38

[8] Hamidi, Y., D., Wennberg, K., Berglund, H., (2008) "Creativity in entrepreneurship education" Journal of Small Business and Enterprise Development"15(2), pp. 304-320.

[9] Heionen, J., \& Poikkijoki, S.,A.,(2006), "An Entrepreneurial-directed approach to entrepreneurship education: mission impossible ?"Journal of Management Development, 25(1), pp. 80-94.

[10] Hills, G.E., "Variations in University entrepreneurship education: An empirical study of an evolving field", Journal of Business Venturing , 3(1) pp.109-22.

[11] Isaacs, E., Visser, K., Friedrich, C. \& Brijal, P. (2007) "Entrepreneurship education and training at the Further Education and Training (FET) level in South Africa" South African Journal of Education.

[12] Jack, Sarah, L., Anderson, \& Alistair,R. (1999) "Entrepreneurship Education Within the Enterprise Culture", International Journal of Entrepreneurial Behaviour \& Research, 5(3), pp.110-125.

[13] Jesslyn, Co., M., \& Mitchell, B. (2006) "Entrepreneurship education in South Africa: A nationwide survey" Education +Thinking, 48(5), pp. 348-359.

[14] Kaijage, E., \& Wheeler, D. (2013) "Supporting Entrepreneurship Education in East Africa" Report for Presentation to Stakeholders. February.

[15] Kautonen, T. Gelderen, M.V. \& Tornikoski ,E.T. (2013) "Predicting Entrepreneurial Behaviour. A Test of the Theory of Planned Behaviour" Applied Economics, 45, pp. 697-707.

[16] Krueger F.Jr.Norris, \& Carsrud Alan, L. (1993) "Entrepreneurial intentions: Applying the theory of planned behaviour" Entrepreneurship And Regional Development: An International Journal, 5(4), pp. 315-330.

[17] Krueger, N. (1993) "The Impact of prior entrepreneurial exposure on perceptions of of new venture feasibility and desirability" Entrepreneurship : Theory and Practice 18, pp. 5-21.

[18] Krueger, N., Reilly, M., D., \& Carsrud,A.,L., (2000) "Competing Models of Entrepreneurial Intentions" Journal Of Business Venturing, 15 (5-6), pp. 411-432. 
[19] Kuratko, D. F. (2005) The Emergence of Entrepreneurship Education: Development, Trends, and Challenges" Entrepreneurship: Theory and Practice, September.

[20] Lans, T., Oganisjana, K., Taks, M., \& Popov, V., (2013) "Learning For Entrepreneurship in Heterogeneous Groups: Experiences from an International, Interdisciplinary Higher Education Student Programme, TRAMES, 17(67/62), 4, pp.383-399.

[21] Long, W. (1983) "The meaning of Entrepreneurship "American Journal of Small Business, Vol VIII,No.2, Oct.-Dec., pp. 47-56.

[22] Matthews, C.H and Moser, S.B. 1995 "Family background and gender: implications for interest in small firm ownership", Entrepreneurship and Regional Development, 7: pp. 365-377.

[23] McDougall, P., P, OVIATT, B., M., (2000) "International Entrepreneurship: The intersection of two research paths" Academy of Management Journal, 43, pp. 902-908.

[24] McMullan, W.E., Chrisman, J.J., \& Vesper, K.H. (2002)." Lessons from successful innovations in entrepreneurial support programming. In Chrisman, J.J., Holbrook, J.A.D., \& Chua, J.H. (eds.), Innovation and Entrepreneurship in Western Canada: From Family Businesses to Multinationals". Calgary, Alberta: University of Calgary Press.

[25] Oviatt B., M., \& McDougall, P. (2005) "Defining International Entrepreneurship and Modelling the Speed Of Internationalization” Entrepreneurship Theory and Practice April, pp. 537-553.

[26] Oosterberbeek, H., Praag Van, M., \& ljsseltein, A. (2010) The Impact of Entrepreneurship Skills and Motivation" European Economic Review, 54(3), pp. 442-454.

[27] Peterman N.,E., \& Kennedy, J., 2003 "Enterprise Education: Influencing Students' Perceptions of Entrepreneurship" Entrepreneurship Theory and Practice, Winter .

[28] Rasmussen, E., A., Sorheim, R., (2006) "Action-based entrepreneurship education" Technovation, 26, pp.185-194.

[29] Sandelowski, M. (1995) "Focus on Qualitative Methods, Sample Size in Qualitative Research" Research in Nursing and Health, 18, pp. 179-183.

[30] Shane, S. \& Venkataraman, S. SHANE, S. (2000), "The Promise of Entrepreneurship as a Field of Research" Academy of Management Review , 25(1), 217-226.

[31] Sherer, R.F., Adams, J., Carley,S., and Wibe, F.A. (1989) "Role model performance effects on development of entrepreneurial career preference, Entrepreneurship Theory and Practise, 13(3) pp. 5381.

[32] Solomon, G.T., Duffy, S., \& Tarabishy, A. (2002). "The state of entrepreneurship education in the United States: A nationwide survey and analysis". International Journal of Entrepreneurship Education, 1(1), 6586.

[33] Stevenson, H.H. (2000). "Why entrepreneurship has won! "Coleman White Paper. USASBE National Conference, February.

[34] Timmons, J.A., Muzyka, D.F., Stevenson,H.,M and Bygrave,W.D., (1987), " Opportunity recognition: the core of entrepreneurship" in Churchill,N., (Ed.) Frontiers of Entrepreneurial Research, Babson College, Babson Park, MA.

[35] Tkachev, A., Kolvereid L., 1999 "Self-employment intentions among Russian students" Entrepreneurship and Regional Development, 11:3, pp. 269-280.

[36] Vesper, K.H. (1999). "Unfinished business (entrepreneurship) of the 20th century". Coleman White Paper. USASBE National Conference, January 1999.

[37] Wu, L., \& Li, J., (2011) "Perceived value of entrepreneurship, A study of the cognitive process of entrepreneurial career decision" Journal of Chinese Entrepreneurship, Vol.3(2) pp.134-146.

[38] (http://www.tuik.gov.tr/PreHaberBultenleri.do?id=18521. Retrieved on 10th.Nov.2015).

[39] (http://www.asiaseed.org. Retrieved on 11th.Nov.2015). 